\title{
The Role of Helper T Cells in Psoriasis
}

\author{
Peng $\mathrm{Hu}^{1,2,3 \dagger}$, Mengyao Wang ${ }^{1,4 \dagger}$, Hu Gao ${ }^{1,4,5 \dagger}$, Ai Zheng ${ }^{1,4}$, Jinhui $\mathrm{Li}^{1,2,3^{\star}}$, \\ Dezhi $\mathrm{Mu}^{1,2,3^{*}}$ and Jiyu Tong ${ }^{1,4,6^{*}}$
}

${ }^{1}$ West China Second University Hospital, Sichuan University, Chengdu, China, ${ }^{2}$ Department of Pediatrics, West China Second University Hospital, Sichuan University, Chengdu, China, ${ }^{3}$ Key Laboratory of Obstetrics \& Gynecologic and Pediatric Diseases and Birth Defects of the Ministry of Education, Sichuan University, Chengdu, China, ${ }^{4}$ Key Laboratory of Birth Defects and Related Diseases of Women and Children, Sichuan University, Ministry of Education, Chengdu, China, ${ }^{5}$ Department of Emergency, West China Second University Hospital, Sichuan University, Chengdu, China, ${ }^{6}$ Department of Immunology, West China School of Basic Medical Sciences and Forensic Medicine, Sichuan University, Chengdu, China

\section{OPEN ACCESS}

Edited by:

Jayendra Kumar Krishnaswamy, Galderma, Switzerland

Reviewed by:

Loredana Frasca,

National Institute of Health (ISS), Italy

Georg Varga,

University Hospital Muenster,

Germany

*Correspondence:

Jinhui Li

yoyolee824@163.com

Dezhi Mu

mudz@scu.edu.cn

Jiyu Tong

jiyu.tong@scu.edu.cn

${ }^{\dagger}$ These authors have contributed equally to this work and

share first authorship

Specialty section:

This article was submitted to

T Cell Biology,

a section of the journal

Frontiers in Immunology

Received: 04 October 2021 Accepted: 25 November 2021 Published: 15 December 2021

Citation: Hu P, Wang M, Gao $H$, Zheng A, Li J, Mu D and Tong J (2021) The Role of Helper T Cells in Psoriasis.

Front. Immunol. 12:788940. doi: 10.3389/fimmu.2021.788940
Psoriasis is a complex, chronic relapsing and inflammatory skin disorder with a prevalence of approximately $2 \%$ in the general population worldwide. Psoriasis can be triggered by infections, physical injury and certain drugs. The most common type of psoriasis is psoriasis vulgaris, which primarily features dry, well-demarcated, raised red lesions with adherent silvery scales on the skin and joints. Over the past few decades, scientific research has helped us reveal that innate and adaptive immune cells contribute to the chronic inflammatory pathological process of psoriasis. In particular, dysfunctional helper T cells (Th1, Th17, Th22, and Treg cells) are indispensable factors in psoriasis development. When stimulated by certain triggers, antigen-presenting cells (APCs) can release pro-inflammatory factors (IL-23, IFN- $\alpha$ and IL-12), which further activate naive $T$ cells and polarize them into distinct helper $\mathrm{T}$ cell subsets that produce numerous cytokines, such as TNF, IFN- $\gamma, \mathrm{IL}-17$ and IL-22, which act on keratinocytes to amplify psoriatic inflammation. In this review, we describe the function of helper $T$ cells in psoriasis and summarize currently targeted anti-psoriatic therapies.

Keywords: Th17, Tregs, psoriasis, cytokines, biologics

\section{INTRODUCTION}

Psoriasis is a complex, chronic relapsing and inflammatory skin disorder with an overall prevalence of $2 \%$ in the general population worldwide (1). The most common type of psoriasis is psoriasis vulgaris, which primarily manifests as dry, well-demarcated, raised red lesions with adherent silvery scales on the skin and joints and accounts for nearly $90 \%$ of all psoriasis cases. Psoriasis is also associated with multiple comorbidities, such as arthritis, obesity, diabetes mellitus, depression, hypertension, cardiovascular disease, and reduced quality of life (2).

Although the exact mechanism that triggers psoriasis remains unclear, it is currently accepted that psoriasis is induced or exacerbated by either nonspecific triggers, such as infections [such as Streptococcus (3)], physical injury [such as scratching and tattoos (4)], drugs [such as $\beta$ blockers, lithium and antimalarials $(5,6)$ ] or some specific autoantigens [such as cathelicidin LL-37, 
melanocytic ADAMTSL5, lipid antigen PLA2G4D and keratin 17 (7)]. Pathologically, psoriasis is characterized by epidermal acanthosis (thickening of the viable layers), hyperkeratosis (thickened cornified layer), and parakeratosis (cell nuclei present in the cornified layer) (8). Over the past 50 years, researchers have performed substantial work to explore the underlying mechanism of the link between skin injury and keratinocyte dysfunction, which drives the development and progression of psoriasis. A series of basic and clinical studies has shown that psoriasis is mediated by components of both the innate and adaptive immune systems. It was reported that innate immune cells such as natural killer (NK) cells, NKT cells, neutrophils, mast cells, $\gamma \delta \mathrm{T}$ cells, and dendritic cells (DCs) were significantly increased in psoriatic lesions and could frequently release pathogenic mediators such as TNF- $\alpha$ and interleukin 23 (IL-23) (9-13). As another important source of cytokines, adaptive immune cells have been the subject of academic interest since 1979. A variety of studies showed that several related cytokines, such as tumor necrosis factor- $\alpha$ (TNF$\alpha$ ), interferon $\gamma($ IFN- $\gamma$ ), interleukin 23 (IL-23), interleukin 17 (IL-17), and interleukin 22 (IL-22), were highly correlated with psoriasis. Recently, autoreactive $\mathrm{T}$ cells against specific autoantigens were also found to produce related pathogenic cytokines, especially IFN- $\gamma$ and IL-17. Lande et al. demonstrated specific CD4 and CD8 T-cell responses and increased IFN- $\gamma$ and IL-17 production to LL37 in psoriatic patients (14), while Arakwa et al. identified ADAMTSL5 as an autoantigen recognized by specific CD8 T-cells (15). Specially, for CD8 T cells, both autoantigens were showed to be presented in the peptide-binding groove of the human leukocyte antigen (HLA)-class I molecule encoded by the major psoriasis risk gene, HLA-Cw ${ }^{\star} 06: 02(14,15)$. Consistently, keratin peptides that share sequences with Streptococcal M-protein can be recognized by $\mathrm{T}$ cells from psoriatic patients (16-18). Subsequent evidences showed that full-length keratin 17 and its peptide fragments induce $\mathrm{T}$ cell proliferation and IFN- $\gamma$ production, particularly in patients with the HLA-Cw*06:02 allele $(19,20)$. Furthermore, clinic studies showed that matched biological agents against these cytokines could also induce effective therapeutic results. Moreover, among them, IL-17, which is mainly produced by $\gamma \delta \mathrm{T}$ cells, CD4+ helper T cells (Th17 cells), and CD8+ cytotoxic T cells (Tc17 cells), seems to be most strongly implicated in psoriasis; thus, $\mathrm{T}$ cells, especially helper $\mathrm{T}$ (Th) cells, have become a hot topic in psoriasis pathogenesis. Here, we reviewed the biogenesis and function of helper $\mathrm{T}$ cells in psoriasis and briefly summarized currently targeted therapies.

\section{ROLE OF HELPER T CELLS IN PSORIASIS}

When Mueller et al. used cyclosporine A, an immunosuppressive agent that inhibits $\mathrm{T}$ cell proliferation and cytokine production, to treat psoriasis and then observed surprising therapeutic efficacy, researchers realized the potential role of $\mathrm{T}$ cells in psoriasis pathogenesis (21). Later, Prinz et al. isolated $10 \mathrm{~T}$ cell lines and $105 \mathrm{~T}$ cell clones from the dermis and epidermis of psoriatic skin specimens and subsequently found that $\mathrm{T}$ cells and their secreted products, such as IFN- $\gamma$, could contribute to keratinocyte proliferation (22). Then, Baker et al. showed that the initial phase of psoriasis was dominated by epidermal infiltration of activated CD4+ T cells, indicating a primary immune trigger for the inflammatory and hyper-proliferative processes (23). In the current model, the crosstalk between keratinocytes and various immune cells, especially helper T cells, plays a central role in the progression of psoriasis (Figure 1).

\section{Th1/Th17/Th22 Cells in Psoriasis}

A study from the University of Mainz investigated cytokines secreted by $\mathrm{T}$ cells obtained from epidermal specimens of psoriatic patients and showed that nearly all $\mathrm{T}$ cells tested produced Th1-related cytokines (IFN- $\gamma$, TNF- $\alpha$, and IL-2), whereas only a minority of cells secreted Th2-related cytokines (IL-4 and IL-10) (24). In the same year, another study suggested that IFN- $\gamma$, which is produced mainly by Th1 cells, is capable of enhancing keratinocyte proliferation in vitro (22). These results defined psoriasis as a Th1 cell-mediated disease. However, the administration of humanized monoclonal antibodies against IFN- $\gamma$ and TNF- $\alpha$ does not significantly improve psoriasis, suggesting that Th1 cells or their related cytokines may not be critical in the pathogenesis of psoriasis (25).

While assessing the involvement of IL-23 in the induction and maintenance of chronic inflammatory diseases, Harrington et al. first recognized the distinct CD4+ T cells - known as Th17 cells $(26,27)$. IL-23, a heterodimeric cytokine composed of a unique p19 chain and a p40 chain that is shared with IL-12, is essential for the survival and development of Th17 cells (28). There is growing evidence to suggest that the IL-23/Th17 axis and the related cytokines have critical roles in psoriasis. Enhanced expression of IL-23 at the mRNA and protein levels could be detected in psoriatic skin compared with healthy skin. Moreover, intradermal injection of IL-23 in murine models can stimulate keratinocyte proliferation and cause epidermal hyperplasia, and anti-IL-12/IL-23 and anti-IL-23 agents have shown highly effective therapeutic effects in clinical trials (29-32). In 2007, Wilson et al. found that Th17 cells may participate in the pathological processes of psoriasis through the coordinated expression of IL-17A, IL-17F, IL-22, IL-21 and IL-26 (33). Both IL-17A and IL-17F are subtypes of IL-17, and they have been shown to be elevated in psoriatic lesions and the peripheral blood of psoriatic patients (34). Clinical randomized trials have shown beneficial effects of IL-17A and IL-17F antibodies, validating IL-17A and IL-17F as potential therapeutic targets (35-38). Further studies demonstrated that IL-22 also mediates IL-23/Th17 axis-induced psoriasis-like skin inflammation (39). Zheng et al. suggested that IL-22, which acts in synergy with IL17, might play an essential role in the pathogenesis of autoimmune diseases such as psoriasis (39). Subsequently, scientific research highlighted that IL-17 and IL-22 may mediate distinct downstream pathways that contribute to the psoriatic phenotype: IL-17 is more pro-inflammatory than IL-22, while IL-22 impairs keratinocyte differentiation (40). In addition, Van Belle et al. showed that IL-22 played major roles not only in the development of pustules and acanthosis but also in 


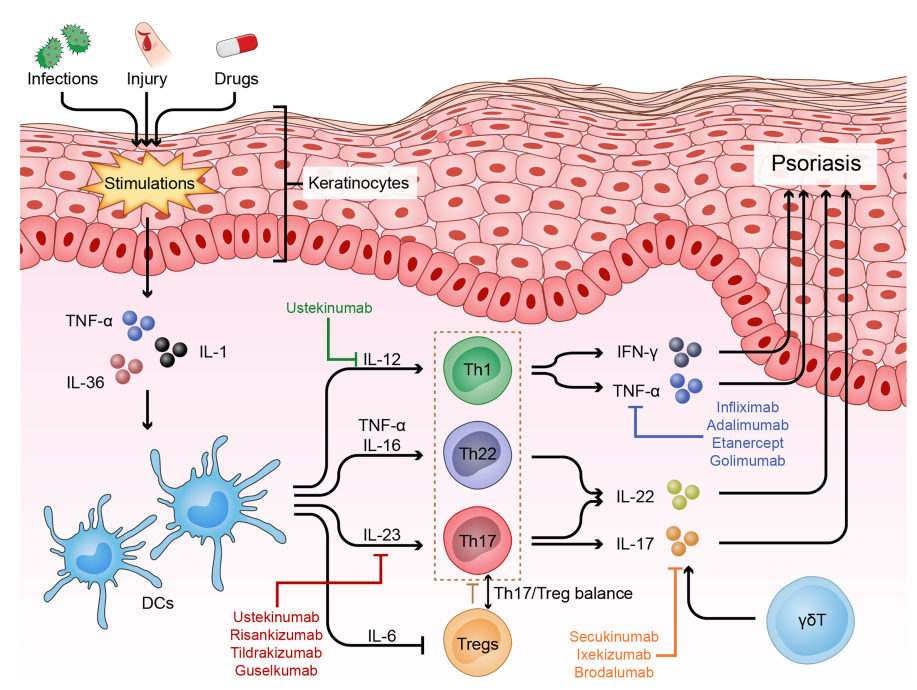

FIGURE 1 | Immune dysfunction of psoriasis. Psoriasis is driven by many nonspecific triggers. Triggers such as infections and physical injury stimulate DCs to release pro-inflammatory factors (IL-23, TNF- $\alpha$ and IL-12). These cytokines in turn activate the IL-23 and/or IL-22 pathway to induce Th17 and/or Th22 cell differentiation, resulting in the production of numerous psoriatic cytokines, such as TNF- $\alpha$, IFN- $\gamma$, IL-17 and IL-22, which act on keratinocytes to amplify psoriatic inflammation. In addition, skin infiltrating cells, such as $\gamma \delta$ T cells, contribute to the disease development via producing IL-17, and Treg cells and the Th17/Treg balance also play important roles in the pathogenesis of psoriasis.

neutrophil infiltration in a mouse model triggered by the Tolllike receptor (TLR) 7/8 agonist imiquimod (41). The IL-23/Th17 axis and the related cytokines could further amplify keratinocyte proliferation and cause epidermal hyperplasia (42).

Later, Nograles et al. discovered a new subtype of $\mathrm{T}$ cells by analyzing the $\mathrm{T}$ cell subsets in skin biopsies and peripheral blood collected from psoriatic patients by intracellular cytokine staining and flow cytometry, and these cells were called Th22 cells (43). Moreover, research from Trifari et al. solidified this view. The researchers identified another population of human helper $\mathrm{T}$ cells that produced abundant IL-22 and IL-13 but no IFN- $\gamma$, IL- 4 or IL17. IL-22, as we described above, is required for the pathogenesis and development of many autoimmune diseases (44). Kagami et al. analyzed $\mathrm{T}$ cell numbers in the circulation of psoriatic patients and showed that in addition to Th1 and Th17 cells, Th22 cells were also increased in psoriatic patients (45). Notably, IL-22 deficiency caused a significant decrease in epidermal acanthosis and dermal inflammation induced by IL-23 (39). These studies established the crucial role of the IL-23/Th17 axis and the IL-22/Th22 pathway in the pathogenesis and development of psoriasis. However, it has been reported that Th1 and Th17 cells may contribute to the pathogenesis and development of psoriasis. Researchers argued that IFN- $\gamma$ secreted mainly by Th1 cells could induce Th17 cells via IL- 1 and IL-23. Furthermore, IFN- $\gamma$ can also stimulate antigenpresenting cells (APCs) to produce CCL20, which is responsible for the migration of IL-17+ T cells (46). Considering the role of IL-22, it can no longer be denied that psoriasis is a Th1/Th17/Th22mediated autoimmune disease.

\section{Treg Cells in Psoriasis}

Treg cells are a special subset of helper $\mathrm{T}$ cells that are characterized by high expression of the CD25, alpha-chain of
IL-2 receptor. Then Foxp3 (Forkhead Box P3), a transcription factor of the fork head/winged-helix family, was found as the most important transcription factor for controlling the development and function of Treg cells. Treg cells can suppress the activities of other effector immune cells mainly by direct contact and/or the secretion of suppressive cytokines, such as IL-10 and transforming growth factor (TGF)- $\beta$ (47). Hence, Treg cells are prominently associated with peripheral tolerance, autoimmune diseases and chronic inflammatory diseases, including psoriasis (48).

Studies investigating the percentage of Treg cells in lesional skin or peripheral blood have contradictory evidence, which varied in different psoriasis subtypes, disease states, Treg definition, and types of samples (49-55). Interestingly, the function of Treg cells was consistently demonstrated to be impaired (56). Both Sugiyama et al. and Li B et al. observed that circulating CD4+CD25+ Treg cells in psoriatic patients failed to suppress the proliferation of normal CD4+CD25responder $\mathrm{T}$ cells during co-culture $(56,57)$. Similar results were reported in pediatric patients (58).

The unstable expression (downregulation) of Foxp3 reflects the dysfunction of Treg cells in psoriasis, and numerous upstream regulators have been reported. One of these regulators is the pro-inflammatory cytokine milieu, especially high levels of IL-6. Indeed, IL-6 was highly expressed in the plasma and lesional skin of psoriatic patients (59). In an in vitro model, Goodman et al. reported that human Treg cell-mediated suppression of responder $\mathrm{T}$ cell proliferation could be reversed by culture with rhIL6 (recombinant human IL-6) or activated DCs, which highly express IL-6 (59). Furthermore, under IL-6 stimulation, elevated phosphorylation of the transcription factor Stat3 was noted in dysfunctional Treg cells (60). Stat3 acts as a 
downstream molecule of IL-6R and can bind to a silencing element within the Foxp3 locus, leading to a reduction in the expression of Foxp3. Furthermore, Zhao et al. reported that increased expression of microRNA-210 in CD4+ T cells from patients with psoriasis vulgaris repressed Foxp3 expression and subsequently inhibited the production of IL-10 and TGF- $\beta$ (61). In addition, in a CD18-knockout mouse model, a spontaneous psoriasiform phenotype was observed, accompanied by Treg cell dysfunction. Adoptive transfer of wild-type Treg cells into CD18-knockout mice markedly reduced the psoriasis area and severity index (PASI) scores. Wang et al. revealed that reduced CD18 expression on CD4+CD25+CD127- Tregs resulted in deceased expression of TGF- $\beta 1$ by disrupting their cell-cell contact with DCs (62).

Because the differentiation of Th17 and Treg cells is reciprocally regulated by shared and different cytokines, it is not surprising that the cytokine milieu of the psoriatic skin microenvironment may cause an imbalance. Zhang et al. and Wang et al. independently reported a positive association between the ratio of Th17 cells to Treg cells in peripheral blood and PASI scores $(51,61)$. As mentioned previously, IL-6, which is a critical cytokine for Th17 differentiation, inhibits Treg cells by inhibiting the expression of Foxp3 in psoriasis pathogenesis (63). Furthermore, a group of IL-17A+/Foxp3 $+/ \mathrm{CD} 4+$ triple-positive cells were identified in the lesional skin of psoriasis patients (64). These cells maintain a high ROR $\gamma t /$ Foxp3 ratio to promote the production of IL-17A. This evidence suggests important plasticity between Th17 and Treg cells in psoriasis (64). Specifically, Singh et al. reported a mechanism by which reduced CD18 levels could promote the conversion of Treg cells to Th17 cells in a CD18-knockout mouse model of psoriasis (65). In addition, Ma et al. showed that the Th17/Treg imbalance was also regulated by the Notch1 signaling pathway, which is known to be a conserved signaling pathway involved in cell development and differentiation of multiple organisms and tissues (66). In their experiments, the expression of Notch1 and its target gene Hes- 1 were positively correlated with PASI scores and the ratios of Th17/Treg cells. Correspondingly, Notch receptor inhibitors reduced the percentage of Th17 cells and the Th17/Treg ratio (66).

Currently, it is relatively clear that Treg cells and the Th17/ Treg balance play important roles in the pathogenesis of psoriasis; however, the underlying mechanisms that drive Treg cell dysfunction and the imbalance in Th17/Treg cells still need to be further investigated.

\section{T Follicular Helper Cells}

$\mathrm{T}$ follicular helper ( $\mathrm{Tfh}$ ) cells, characterized by the high expression of chemokine CXC receptor 5 (CXCR5), are another specialized subset of CD4+ T cells. With expression of IL-21, CXCL13 and PD-1, they exert B helper activities in a manner primarily dependent on IL-21 (67). Tfh cells can be further classified as three subpopulations, including Type 17 (CXCR3-CCR6+), Type 1 (CXCR3 + CCR6-), and Type 2 (CXCR3-CCR6-) cells. Recently, Tfh cells have been shown to be involved in the pathogenesis of psoriasis. Niu et al. and Wang et al. demonstrated that the frequency of circulating Tfh were elevated in psoriasis and positively correlated with serum IL-21 levels and PASI scores $(68,69)$, suggesting Tfh cells as potential contributors to psoriasis pathogenesis. Moreover, Caruso et al. reported that increased IL-21 was produced primarily by CD4+ $\mathrm{T}$ cells in psoriatic lesions (70). Although other markers, like CXCR5, were not analyzed to define CD4+ T cell subsets, a part of the IL-21-producing CD4 T cells were co-producing IFN- $\gamma$ or IL-17. Consistently, Wang et al. observed that CXCR3-CCR6+ Tfh type 17 subset, which secrete the Th17 cytokines IL-17A and IL-22, increased and correlated with PASI score in psoriasis (71).

\section{TARGETED PSORIASIS THERAPIES}

Recognition of the IL-23/Th17 axis and IL-22/Th22 pathway vigorously promoted the development of targeted therapies. To date, targeted therapies that have been approved by the Food and Drug Administration (FDA) for psoriasis treatment have shown promising effects $(72,73)$. There are also various new biologic agents that exhibit promising therapeutic efficacy in clinical trials (72, 73). Table 1 shows the targeted agents for psoriasis treatment, and we briefly discuss the agents targeting the IL23/Th17 axis and IL-22/Th22 pathway in the treatment of psoriasis.

\section{Targeting IL-23}

IL-23 is a heterodimeric cytokine composed of a unique p19 chain and a p40 chain shared with IL-12. Targeted drugs include antibodies that inhibit the p19 subunit of IL-23 and the p40 subunit of both IL-12 and IL-23. Ustekinumab and Briakinumab, which are human interleukin-12/23 monoclonal antibodies, have been approved by the FDA and have shown significant efficacy in patients with moderate to severe plaque psoriasis $(29,32)$. Risankizumab and Tildrakizumab are agents that target the unique IL-23 subunit p19. The results of randomized controlled, phase 3 trials showed that these agents have superior efficacy to placebo or Ustekinumab in the treatment of moderate-to-severe plaque psoriasis $(30,31)$. Data from clinical trials have shown that IL-23 inhibitors have convincing safety profiles; however, long-term observations indicate that adverse events still occur during the treatment. A multicentre, randomized, double-blind, placebo-controlled clinical trial of Ustekinumab showed that adverse events were observed in 217 (53.1\%) patients in the $45 \mathrm{mg}$ group, 197 (47.9\%) in the $90 \mathrm{mg}$ group and $204(49.8 \%)$ in the placebo group (80). The most common adverse effects included infections, headache and injection-site reactions (98).

\section{Targeting IL-17}

Additional categories of biologic agents include fully human interleukin-17A/F monoclonal antibodies. Secukinumab and Ixekizumab can directly neutralize IL-17A and have excellent and sustained efficacy for psoriatic patients with or without PsA and nail psoriasis $(37,38,90,99-101)$. Bimekizumab, a human anti-IL-17 drug that inhibits both IL-17A and IL-17F, induced convincing clinical improvements in psoriatic patients with or 
TABLE 1 | US food and drug administration-approved biologic treatments for psoriasis.

\begin{tabular}{|c|c|c|c|c|c|c|}
\hline \multirow[t]{2}{*}{ Biologics } & \multirow[t]{2}{*}{ Drug } & \multirow[t]{2}{*}{ Main Trials (Reference) } & \multirow[t]{2}{*}{$\mathbf{N}$} & \multirow[t]{2}{*}{ Control Intervention } & \multicolumn{2}{|c|}{ Efficacy (VS Control Intervention) } \\
\hline & & & & & PASI 75 & PASI 90 \\
\hline \multirow[t]{10}{*}{ Anti-TNF } & Etanercept & Papp et al. (74) & 583 & PBO & 49\% at week 12 (VS 3\%) & $21 \%$ at week 12 (VS 1\%) \\
\hline & Infliximab & Reich et al. (75) & 378 & PBO & $80 \%$ at week 10 (VS 3\%) & $57 \%$ at week 10 (VS 1\%) \\
\hline & & & & & $82 \%$ at week 24 (VS 4\%) & $58 \%$ at week 24 (VS 1\%) \\
\hline & & & & & $61 \%$ at week 50 (VS N/A) & $45 \%$ at week 50 (VS N/A) \\
\hline & & Barker et al. (76) & 868 & MTX & $78 \%$ at week 16 (VS 42\%) & $54.5 \%$ at week 16 (VS 19.1\%) \\
\hline & & & & & $76.9 \%$ at week 26 (VS 30.7\%) & $51.0 \%$ at week 26 (VS 14.9\%) \\
\hline & Adalimumab & Menter et al. (77) & 1212 & PBO & $71 \%$ at week 16 (VS 7\%) & $\mathrm{N} / \mathrm{A}$ \\
\hline & Certolizumab & Gottlieb et al. (78) & 461 & PBO & $82 \%$ at week 16 (VS 9.9\%) & $52.2 \%$ at week 16 (VS 2.5\%) \\
\hline & pegol & & & & $83.6 \%$ at week 48 (VS N/A) & \\
\hline & & Lebwohl et al. (79) & 224 & Etanercept & $66.7 \%$ at week 12 (VS 53.3\%) & $\mathrm{N} / \mathrm{A}$ \\
\hline \multirow[t]{18}{*}{ Anti-IL-23 } & Ustekinumab & Leonardi et al. (32) & 511 & PBO & $66.4 \%$ at week 12 (VS 3.1\%) & $36.7 \%$ at week 12 (VS 2.0\%) \\
\hline & & & & & $78.6 \%$ at week 28 (VS N/A) & $55.6 \%$ at week 28 (VS N/A) \\
\hline & & Papp et al. (80) & 821 & PBO & $75.7 \%$ at week 12 (VS 3.7\%) & $50.9 \%$ at week 12 (VS 0.7\%) \\
\hline & & & & & $78.5 \%$ at week 28 (VS N/A) & $54.3 \%$ at week 28 (VS N/A) \\
\hline & Briakinumab & Gottlieb et al. (81) & 347 & Etanercept/PBO & $81.9 \%$ at week 12 (VS 56.0\%/7.4\%) & $\mathrm{N} / \mathrm{A}$ \\
\hline & & Strober et al. (29) & 350 & Etanercept/PBO & $80.6 \%$ at week 12 (VS 39.6\%/6.9\%) & $55.4 \%$ at week 12 (VS 13.7\%/4.2\%) \\
\hline & Tildrakizumab & Reich et al. (31) & 463 & PBO & $62 \%$ at week 12 (VS 6\%) & $35 \%$ at week 12 (VS 3\%) \\
\hline & & & 783 & Etanercept/PBO & $66 \%$ at week 12 (VS 48\%/6\%) & $37 \%$ at week 12 (VS 21\%/1\%) \\
\hline & Guselkumab & Blauvelt et al. (82) & 663 & Adalimumab & $91.2 \%$ at week 16 (VS 73.1\%) & $73.3 \%$ at week 16 (VS 49.7\%) \\
\hline & & & & & $91.2 \%$ at week 24 (VS 72.2\%) & $80.2 \%$ at week 24 (VS 53.0\%) \\
\hline & & & & & $87.8 \%$ at week 48 (VS 62.6\%) & $76.3 \%$ at week 48 (VS 47.9\%) \\
\hline & & Reich et al. (83) & 1048 & Secukinumab & $85 \%$ at week 48 (VS 80\%) & $84 \%$ at week 48 (VS 70\%) \\
\hline & & Thaçi et al. (84) & 119 & FAE & 90.0\% at week 24 (VS 27.1\%) & $81.7 \%$ at week 24 (VS 13.6\%) \\
\hline & Risankizumab & Gordon et al. (30) & 506 & Ustekinumab/PBO & N/A & 75.3\% at week 16 (VS 42\%/4.9\%) \\
\hline & & & 491 & Ustekinumab/PBO & $\mathrm{N} / \mathrm{A}$ & $74.8 \%$ at week 16 (VS 47.5\%/2.0\%) \\
\hline & & Reich et al. (85) & 605 & Adalimumab & $91 \%$ at week 16 (VS 72\%) & $72 \%$ at week 16 (VS 47\%) \\
\hline & & Warren et al. (86) & 327 & Secukinumab & $92 \%$ at week 16 (VS 80\%) & $74 \%$ at week 16 (VS 66\%) \\
\hline & & & & & 90\% at week 52 (VS 70\%) & $87 \%$ at week 52 (VS 57\%) \\
\hline \multirow[t]{19}{*}{ Anti-IL-17 } & Secukinumab & Langley et al. (38) & 493 & PBO & $81.6 \%$ at week 12 (VS 4.5\%) & $59.2 \%$ at week 12 (VS 1.2\%) \\
\hline & & & 979 & Etanercept/PBO & $77.1 \%$ at week 12 (VS 44\%/4.9\%) & $54.2 \%$ at week 12 (VS 20.7\%/1.5\%) \\
\hline & & Thaçi et al. (87) & 676 & Ustekinumab & 93.1\% at week 16 (VS 82.7\%) & $79.0 \%$ at week 16 (VS 57.6\%) \\
\hline & & Blauvelt 2017 (88) & 676 & Ustekinumab & 92.5\% at week 24 (VS 83.6\%) & 80.8\% at week 24 (VS 66.3\%) \\
\hline & & & & & $91.6 \%$ at week 52 (VS 78.2\%) & $74.9 \%$ at week 52 (VS 60.6\%) \\
\hline & & Bagel et al. (89) & 1102 & Ustekinumab & 89.0\% at week 52 (VS 82.1\%) & $73.2 \%$ at week 52 (VS 59.8\%) \\
\hline & Ixekizumab & Griffiths et al. (90) & 877 & Etanercept/PBO & $89.7 \%$ at week 12 (VS 41.6\%/2.4\%) & $70.7 \%$ at week 12 (VS 18.7\%/0.6\%) \\
\hline & & & 960 & Etanercept/PBO & 87.3\% at week 12 (VS 53.4\%/7.3\%) & $68.1 \%$ at week 12 (VS 25.7\%/3.1\%) \\
\hline & & Gordon et al. (91) & 864 & PBO & 89.1\% at week 12 (VS 3.9\%) & $70.9 \%$ at week 12 (VS 0.5\%) \\
\hline & & & 385 & $\mathrm{~N} / \mathrm{A}$ & $83 \%$ at week 60 & $73 \%$ at week 60 \\
\hline & & Blauvelt et al. (92) & 385 & $\mathrm{~N} / \mathrm{A}$ & $83.6 \%$ at week 108 & $70.3 \%$ at week 108 \\
\hline & & Lebwohl et al. (93) & 385 & $\mathrm{~N} / \mathrm{A}$ & $82.8 \%$ at week 204 & $48.3 \%$ at week 204 \\
\hline & & Reich et al. (94) & 162 & MTX/FAE & 91\% at week 24 (VS 70\%/22\%) & $80 \%$ at week 24 (VS 39\%/9\%) \\
\hline & & Blauvelt et al. (95) & 1027 & Guselkumab & 23\% at week 2 (VS 5\%) & $58 \%$ at week 8 (VS 36\%) \\
\hline & & & & & No statistically difference at week 24 & No statistically difference at week 24 \\
\hline & Brodalumab & Lebwohl et al. (96) & 1221 & Ustekinumab/PBO & $86 \%$ at week 12 (VS 70\%/8\%) & $\mathrm{N} / \mathrm{A}$ \\
\hline & & Papp et al. (36) & 1252 & Ustekinumab/PBO & 85\% at week 12 (VS 69\%/6\%) & $\mathrm{N} / \mathrm{A}$ \\
\hline & & & 441 & PBO & 83.3\% at week 12 (VS 2.7\%) & $70.3 \%$ at week 12 (VS 0.9\%) \\
\hline & & Pinter et al. (97) & 149 & FAE & $81.0 \%$ at week 24 (VS 38.1\%) & $65.7 \%$ at week 12 (VS 21.9\%) \\
\hline
\end{tabular}

TNF, tumor necrosis factor; N, Number of participants; PASI 75/90, a 75\%/90\% reduction in Psoriasis Area Severity Index (PASI) score compared with baseline; N/A, Not Applicable; MTX, Methotrexate; FAE, fumaric acid esters; $P B O$, Placebo.

without psoriatic arthritis $(35,102)$. Brodalumab is a human anti-IL-17 receptor antagonist (IL-17RA) (36). The feature that broadly blocks IL-17A, IL-17F, IL-17C and IL-17E enables IL17RA to rapidly improve the clinical and histological features of psoriasis (103). It was shown that Brodalumab may even be effective in those who failed to respond to Secukinumab and Ixekizumab $(103,104)$. Although all these antagonists showed robust efficacy, unexpected side effects have also been reported. The most common adverse effects are infections, such as bacterial infection and tuberculosis; others, such as headache and diarrhea, are less common (73).

\section{Targeting IL-22}

IL-22 is an essential cytokine for psoriasis development. ILV095, an IL-22 receptor antagonist that was developed to treat psoriasis, failed in a phase I clinical trial because the expected endpoints could not be met (105). Another humanized monoclonal antibody against the IL-22 receptor, IL-094, was 
suspended for similar reasons (105). Thus far, biological therapies against the IL-22 receptor need to be further investigated in the future.

\section{Targeting JAK/STAT Pathway}

The Janus kinase (JAK) signal transducer and activator of transcription (STAT) signaling pathway (JAK/STAT pathway) transduce signals from multitudes of cytokines and growth factors and plays a major role in the pathogenesis of many inflammatory and autoimmune diseases. Due to the essential role in forwarding the IL-23/Th17 axis and IL-22/Th22 pathway signals into cell, JAK/STAT pathway has received increasing attention recently in psoriasis (106). Furthermore, it is an attractive idea that to blockade multiple psoriasis related cytokines rather than specific to one signaling pathway by inhibiting of JAKs. Indeed, there are already several biologic agents that target JAK/STAT pathway in clinical trials: Tofacitinib (NCT01241591) for JAK1 and JAK3 (107); Baricitinib (NCT01490632) for JAK1 and JAK2 (108); Itacitinib (NCT01634087) and Solcitinib (NCT01782664) for JAK1 (109, 110); PF-06700841 (NCT02969018) for JAK1 and TYK2 (111); and PF-06826647 (NCT03895372) and Deucravacitinib (NCT03924427) for TYK2 $(112,113)$. Many of them have shown promising efficacy, especially selective TYK2 inhibitors, whereas the adverse effect and long-term safety still need to be emphasized.

\section{CONCLUSIONS}

Over the past 50 years, substantial scientific research has suggested that $\mathrm{T}$ cells are closely associated with the pathogenesis of psoriasis. These cells serve as a link connecting nonspecific triggers and keratinocyte dysfunction. Triggers such as infections and physical injury stimulate antigen-presenting cells (APCs) to release pro-inflammatory factors (IL-23, IFN- $\alpha$ and IL-12). These cytokines in turn activate the IL-23 and/or IL-22 pathway to induce Th17 and/or Th22 cell differentiation, resulting in the production of numerous psoriatic cytokines, such as TNF, IFN- $\gamma$, IL-17 and IL-22, which act on keratinocytes to amplify psoriatic inflammation. Nowadays, on the one hand, the observation that Treg and/or Th17/Treg balance is frequently dysregulated in psoriatic patients hints at the critical role of Treg cells in controlling psoriatic inflammation. One possible mechanism by which the Th17/Treg balance is disturbed in

\section{REFERENCES}

1. Lowes MA, Suarez-Farinas M, Krueger JG. Immunology of Psoriasis. Annu Rev Immunol (2014) 32:227-55. doi: 10.1146/annurev-immunol-032713120225

2. Griffiths CE, Barker JN. Pathogenesis and Clinical Features of Psoriasis. Lancet (London England) (2007) 370(9583):263-71. doi: 10.1016/s01406736(07)61128-3

3. Groot J, Blegvad C, Nybo Andersen AM, Zachariae C, Skov L. Tonsillitis and Pediatric Psoriasis: Cohort and Cross-Sectional Analyses of Offspring From psoriatic lesions attributes to the high levels of IL-6. And Tfh cells, which has been proved to be one of the major sources of IL21 , are also involve in the pathogenesis of psoriasis. Additionally, it has been reported that $\gamma \delta \mathrm{T}$ cells, which are the major IL-17producing cells in the skin, also play critical roles in psoriasis pathogenesis. On the other hand, biological agents targeting TNF, IL-23 and IL-17 have shown promising efficacy during the clinical treatment of psoriasis, while IL-6 inhibitors, IL-21 inhibitors and recombinant human IL-10 treatment didn't attain the results as expected. Moreover, many clinical trials are ongoing to uncover new targets in psoriasis. For example, JAK inhibitors paved the way of inhibiting multiple pro-inflammatory cytokines together and have shown clinical efficacy in both phase II and III trials. All these advancements are ascribed to the continuous exploration of the pathogenesis of psoriasis. However, there are still some issues that need to be addressed. First, adverse events cannot be ignored during treatment, which may be feasibly due to the broad biological effects of these cytokines. In addition, several limitations, such as the difficulty of effecting a cure, the need for long-term medication and ease of recurrence after drug withdrawal, still exist. All this evidence highlights that our understanding of psoriasis is insufficient, especially the crosstalk of multiple immune cells and cytokines in psoriasis, which still needs to be studied in depth. Further studies should focus on identifying current therapeutic approaches and novel, efficient targets to help overcome the adverse effects and limitations.

\section{AUTHOR CONTRIBUTIONS}

JL, DM and JT conceived of the presented idea. PH, and MW summarized the reference and draft the manuscript. HG organized the figure and table. JL, DM and JT supervised the project and contributed equally to the final version of the manuscript. All authors contributed to the article and approved the submitted version.

\section{FUNDING}

This work was supported by the National Natural Science Foundation of China (32170905, 81801550,81630038 and 81971433); the Danish National Birth Cohort. J Am Acad Dermatol (2020) 82(3):66674. doi: 10.1016/j.jaad.2019.08.010

4. Kluger N, Estève E, Fouéré S, Dupuis-Fourdan F, Jegou MH, Lévy-Rameau C. Tattooing and Psoriasis: A Case Series and Review of the Literature. Int $J$ Dermatol (2017) 56(8):822-7. doi: 10.1111/ijd.13646

5. Awad VM, Sakhamuru S, Kambampati S, Wasim S, Malik BH. Mechanisms of Beta-Blocker Induced Psoriasis, and Psoriasis De Novo at the Cellular Level. Cureus (2020) 12(7):e8964. doi: 10.7759/cureus.8964

6. Balak DM, Hajdarbegovic E. Drug-Induced Psoriasis: Clinical Perspectives. Psoriasis (Auckland NZ) (2017) 7:87-94. doi: 10.2147/ptt.S126727 
7. Ten Bergen LL, Petrovic A, Aarebrot AK, Appel S. Current Knowledge on Autoantigens and Autoantibodies in Psoriasis. Scand J Immunol (2020) 92 (4):e12945. doi: 10.1111/sji.12945

8. Boehncke WH, Schön MP. Psoriasis. Lancet (London England) (2015) 386 (9997):983-94. doi: 10.1016/s0140-6736(14)61909-7

9. Kastelan M, Prpic Massari L, Gruber F, Zamolo G, Zauhar G, Coklo M, et al. Perforin Expression Is Upregulated in the Epidermis of Psoriatic Lesions. Br J Dermatol (2004) 151(4):831-6. doi: 10.1111/j.1365-2133. 2004.06168.x

10. Ottaviani C, Nasorri F, Bedini C, de Pita O, Girolomoni G, Cavani A. CD56brightCD16(-) NK Cells Accumulate in Psoriatic Skin in Response to CXCL10 and CCL5 and Exacerbate Skin Inflammation. Eur J Immunol (2006) 36(1):118-28. doi: 10.1002/eji.200535243

11. Lin AM, Rubin CJ, Khandpur R, Wang JY, Riblett M, Yalavarthi S, et al. Mast Cells and Neutrophils Release IL-17 Through Extracellular Trap Formation in Psoriasis. J Immunol (Baltimore Md 1950) (2011) 187(1):490-500. doi: 10.4049/jimmunol.1100123

12. Martin B, Hirota K, Cua DJ, Stockinger B, Veldhoen M. Interleukin-17Producing Gammadelta T Cells Selectively Expand in Response to Pathogen Products and Environmental Signals. Immunity (2009) 31(2):321-30. doi: 10.1016/j.immuni.2009.06.020

13. Deng YX, Chang C, Lu QJ. The Inflammatory Response in Psoriasis: A Comprehensive Review. Clin Rev Allergy Immunol (2016) 50(3):377-89. doi: 10.1007/s12016-016-8535-x

14. Lande R, Botti E, Jandus C, Dojcinovic D, Fanelli G, Conrad C, et al. The Antimicrobial Peptide LL37 Is a T-Cell Autoantigen in Psoriasis. Nat Commun (2014) 5:5621. doi: 10.1038/ncomms6621

15. Arakawa A, Siewert K, Stohr J, Besgen P, Kim SM, Ruhl G, et al. Melanocyte Antigen Triggers Autoimmunity in Human Psoriasis. J Exp Med (2015) 212 (13):2203-12. doi: 10.1084/jem.20151093

16. Valdimarsson H, Sigmundsdóttir H, Jónsdóttir I. Is Psoriasis Induced by Streptococcal Superantigens and Maintained by M-Protein-Specific T Cells That Cross-React With Keratin? Clin Exp Immunol (1997) 107 Suppl 1:21-4. doi: 10.3389/fimmu.2018.01390

17. Gudmundsdottir AS, Sigmundsdottir H, Sigurgeirsson B, Good MF, Valdimarsson H, Jonsdottir I. Is an Epitope on Keratin 17 a Major Target for Autoreactive T Lymphocytes in Psoriasis? Clin Exp Immunol (1999) 117 (3):580-6. doi: 10.1046/j.1365-2249.1999.01013.x

18. Johnston A, Gudjonsson JE, Sigmundsdottir H, Love TJ, Valdimarsson H. Peripheral Blood T Cell Responses to Keratin Peptides That Share Sequences With Streptococcal M Proteins Are Largely Restricted to Skin-Homing CD8(+) T Cells. Clin Exp Immunol (2004) 138(1):83-93. doi: 10.1111/ j.1365-2249.2004.00600.x

19. Valdimarsson H, Thorleifsdottir RH, Sigurdardottir SL, Gudjonsson JE, Johnston A. Psoriasis-as an Autoimmune Disease Caused by Molecular Mimicry. Trends Immunol (2009) 30(10):494-501. doi: 10.1016/ j.it.2009.07.008

20. Yunusbaeva M, Valiev R, Bilalov F, Sultanova Z, Sharipova L, Yunusbayev B. Psoriasis Patients Demonstrate HLA-Cw06:02 Allele Dosage-Dependent T Cell Proliferation When Treated With Hair FollicleDerived Keratin 17 Protein. Sci Rep (2018) 8(1):6098. doi: 10.1038/s41598018-24491-z

21. Mueller W, Herrmann B. Cyclosporin A for Psoriasis. New Engl J Med (1979) 301(10):555. doi: 10.1056/NEJM197909063011016

22. Prinz JC, Gross B, Vollmer S, Trommler P, Strobel I, Meurer R, et al. T-Cell Clones From Psoriasis Skin-Lesions Can Promote Keratinocyte Proliferation In-Vitro via Secreted Products. Eur J Immunol (1994) 24(3):593-8. doi: 10.1002/eji.1830240315

23. Baker BS, Swain AF, Fry L, Valdimarsson H. Epidermal Lymphocytes-T and Hla-Dr Expression in Psoriasis. Br J Dermatol (1984) 110(5):555-64. doi: 10.1016/B978-0-407-00338-5.50047-8

24. Schlaak JF, Buslau M, Jochum W, Hermann E, Girndt M, Gallati H, et al. T-Cells Involved in Psoriasis Vulgaris Belong to the Th1 Subset. J Invest Dermatol (1994) 102(2):145-9. doi: 10.1111/1523-1747.ep12371752

25. Harden JL, Johnson-Huang LM, Chamian MF, Lee E, Pearce T, Leonardi CL, et al. Humanized Anti-IFN-Gamma (HuZAF) in the Treatment of Psoriasis. J Allergy Clin Immunol (2015) 135(2):553-6. doi: 10.1016/ j.jaci.2014.05.046
26. Aggarwal S, Ghilardi N, Xie MH, de Sauvage FJ, Gurney AL. Interleukin-23 Promotes a Distinct CD4 T Cell Activation State Characterized by the Production of Interleukin-17. J Biol Chem (2003) 278(3):1910-4. doi: 10.1074/jbc.M207577200

27. Harrington LE, Hatton RD, Mangan PR, Turner H, Murphy TL, Murphy $\mathrm{KM}$, et al. Interleukin 17-Producing CD4+ Effector T Cells Develop via a Lineage Distinct From the T Helper Type 1 and 2 Lineages. Nat Immunol (2005) 6(11):1123-32. doi: 10.1038/ni1254

28. Piskin G, Sylva-Steenland RM, Bos JD, Teunissen MB. In Vitro and In Situ Expression of IL-23 by Keratinocytes in Healthy Skin and Psoriasis Lesions: Enhanced Expression in Psoriatic Skin. J Immunol (Baltimore Md 1950) (2006) 176(3):1908-15. doi: 10.4049/jimmunol.176.3.1908

29. Strober BE, Crowley JJ, Yamauchi PS, Olds M, Williams DA. Efficacy and Safety Results From a Phase III, Randomized Controlled Trial Comparing the Safety and Efficacy of Briakinumab With Etanercept and Placebo in Patients With Moderate to Severe Chronic Plaque Psoriasis. Br J Dermatol (2011) 165(3):661-8. doi: 10.1111/j.1365-2133.2011.10419.x

30. Gordon KB, Strober B, Lebwohl M, Augustin M, Blauvelt A, Poulin Y, et al. Efficacy and Safety of Risankizumab in Moderate-to-Severe Plaque Psoriasis (UltIMMa-1 and UltIMMa-2): Results From Two Double-Blind, Randomised, Placebo-Controlled and Ustekinumab-Controlled Phase 3 Trials. Lancet (London England) (2018) 392(10148):650-61. doi: 10.1016/ s0140-6736(18)31713-6

31. Reich K, Papp KA, Blauvelt A, Tyring SK, Sinclair R, Thaçi D, et al. Tildrakizumab Versus Placebo or Etanercept for Chronic Plaque Psoriasis (reSURFACE 1 and reSURFACE 2): Results From Two Randomised Controlled, Phase 3 Trials. Lancet (London England) (2017) 390 (10091):276-88. doi: 10.1016/s0140-6736(17)31279-5

32. Leonardi CL, Kimball AB, Papp KA, Yeilding N, Guzzo C, Wang Y, et al. Efficacy and Safety of Ustekinumab, a Human Interleukin-12/23 Monoclonal Antibody, in Patients With Psoriasis: 76-Week Results From a Randomised, Double-Blind, Placebo-Controlled Trial (PHOENIX 1). Lancet (London England) (2008) 371(9625):1665-74. doi: 10.1016/S01406736(08)60725-4

33. Wilson NJ, Boniface K, Chan JR, McKenzie BS, Blumenschein WM, Mattson JD, et al. Development, Cytokine Profile and Function of Human Interleukin 17-Producing Helper T Cells. Nat Immunol (2007) 8(9):950-7. doi: 10.1038/ ni1497

34. Lowes MA, Kikuchi T, Fuentes-Duculan J, Cardinale I, Zaba LC, Haider AS, et al. Psoriasis Vulgaris Lesions Contain Discrete Populations of Th1 and Th17 T Cells. J Invest Dermatol (2008) 128(5):1207-11. doi: 10.1038/ sj.jid. 5701213

35. Papp KA, Merola JF, Gottlieb AB, Griffiths CEM, Cross N, Peterson L, et al. Dual Neutralization of Both Interleukin 17A and Interleukin 17F With Bimekizumab in Patients With Psoriasis: Results From BE ABLE 1, a 12Week Randomized, Double-Blinded, Placebo-Controlled Phase 2b Trial. J Am Acad Dermatol (2018) 79(2):277-+. doi: 10.1016/j.jaad.2018.03.037

36. Papp KA, Reich K, Paul C, Blauvelt A, Baran W, Bolduc C, et al. A Prospective Phase III, Randomized, Double-Blind, Placebo-Controlled Study of Brodalumab in Patients With Moderate-to-Severe Plaque Psoriasis. Br J Dermatol (2016) 175(2):273-86. doi: 10.1111/bjd.14493

37. Leonardi C, Maari C, Philipp S, Goldblum O, Zhang L, Burkhardt N, et al. Maintenance of Skin Clearance With Ixekizumab Treatment of Psoriasis: Three-Year Results From the UNCOVER-3 Study. J Am Acad Dermatol (2018) 79(5):824-30 e2. doi: 10.1016/j.jaad.2018.05.032

38. Langley RG, Elewski BE, Lebwohl M, Reich K, Griffiths CE, Papp K, et al. Secukinumab in Plaque Psoriasis-Results of Two Phase 3 Trials. New Engl J Med (2014) 371(4):326-38. doi: 10.1056/NEJMoa1314258

39. Zheng Y, Danilenko DM, Valdez P, Kasman I, Eastham-Anderson J, Wu JF, et al. Interleukin-22, a $\mathrm{T}(\mathrm{H}) 17$ Cytokine, Mediates IL-23-Induced Dermal Inflammation and Acanthosis. Nature (2007) 445(7128):648-51. doi: 10.1038/nature05505

40. Nograles KE, Zaba LC, Guttman-Yassky E, Fuentes-Duculan J, SuarezFarinas M, Cardinale I, et al. Th17 Cytokines Interleukin (IL)-17 and IL-22 Modulate Distinct Inflammatory and Keratinocyte-Response Pathways. Br J Dermatol (2008) 159(5):1092-102. doi: 10.1111/j.1365-2133.2008.08769.x

41. Van Belle AB, de Heusch M, Lemaire MM, Hendrickx E, Warnier G, Dunussi-Joannopoulos K, et al. IL-22 Is Required for Imiquimod-Induced 
Psoriasiform Skin Inflammation in Mice. J Immunol (2012) 188(1):462-9. doi: 10.4049/jimmunol.1102224

42. Schon MP, Erpenbeck L. The Interleukin-23/Interleukin-17 Axis Links Adaptive and Innate Immunity in Psoriasis. Front Immunol (2018) 9:1323. doi: 10.3389/fimmu.2018.01323

43. Nograles KE, Zaba LC, Shemer A, Fuentes-Duculan J, Cardinale I, Kikuchi T, et al. IL-22-Producing "T22" T Cells Account for Upregulated IL-22 in Atopic Dermatitis Despite Reduced IL-17-Producing T(H)17 T Cells. J Allergy Clin Immunol (2009) 123(6):1244-52. doi: 10.1016/j.jaci.2009.03.041

44. Trifari S, Kaplan CD, Tran EH, Crellin NK, Spits H. Identification of a Human Helper T Cell Population That has Abundant Production of Interleukin 22 and Is Distinct From T-H-17, T(H)1 and T(H)2 Cells. Nat Immunol (2009) 10(8):864-U73. doi: 10.1038/ni.1770

45. Kagami S, Rizzo HL, Lee JJ, Koguchi Y, Blauvelt A. Circulating Th17, Th22, and Th1 Cells Are Increased in Psoriasis. J Invest Dermatol (2010) 130 (5):1373-83. doi: 10.1038/jid.2009.399

46. Kryczek I, Bruce AT, Gudjonsson JE, Johnston A, Aphale A, Vatan L, et al. Induction of IL-17(+) T Cell Trafficking and Development by IFN-Gamma: Mechanism and Pathological Relevance in Psoriasis. J Immunol (2008) 181 (7):4733-41. doi: 10.4049/jimmunol.181.7.4733

47. Sakaguchi S, Yamaguchi T, Nomura T, Ono M. Regulatory T Cells and Immune Tolerance. Cell (2008) 133(5):775-87. doi: 10.1016/ j.cell.2008.05.009

48. Nussbaum L, Chen YL, Ogg GS. Role of Regulatory T Cells in Psoriasis Pathogenesis and Treatment. Br J Dermatol (2021) 184(1):14-24. doi: 10.1111/bjd.19380

49. Priyadarssini M, Divya Priya D, Indhumathi S, Rajappa M, Chandrashekar L, Thappa DM. Immunophenotyping of $\mathrm{T}$ Cells in the Peripheral Circulation in Psoriasis. Br J Biomed Sci (2016) 73(4):174-9. doi: 10.1080/ 09674845.2016.1207869

50. Richetta AG, Mattozzi C, Salvi M, Giancristoforo S, D'Epiro S, Milana B, et al. CD4+ CD25+ T-Regulatory Cells in Psoriasis. Correlation Between Their Numbers and Biologics-Induced Clinical Improvement. Eur J Dermatol EJD (2011) 21(3):344-8. doi: 10.1684/ejd.2011.1362

51. Zhang L, Yang XQ, Cheng J, Hui RS, Gao TW. Increased Th17 Cells are Accompanied by FoxP3(+) Treg Cell Accumulation and Correlated With Psoriasis Disease Severity. Clin Immunol (Orlando Fla) (2010) 135(1):10817. doi: 10.1016/j.clim.2009.11.008

52. Yun WJ, Lee DW, Chang SE, Yoon GS, Huh JR, Won CH, et al. Role of CD4CD25FOXP3 Regulatory T Cells in Psoriasis. Ann Dermatol (2010) 22 (4):397-403. doi: 10.5021/ad.2010.22.4.397

53. Yan KX, Fang X, Han L, Zhang ZH, Kang KF, Zheng ZZ, et al. Foxp3+ Regulatory T Cells and Related Cytokines Differentially Expressed in Plaque vs. Guttate Psoriasis Vulgaris. Br J Dermatol (2010) 163(1):48-56. doi: $10.1111 /$ j.1365-2133.2010.09742.x

54. Fujimura T, Okuyama R, Ito Y, Aiba S. Profiles of Foxp3+ Regulatory T Cells in Eczematous Dermatitis, Psoriasis Vulgaris and Mycosis Fungoides. $\mathrm{Br} \mathrm{J}$ Dermatol (2008) 158(6):1256-63. doi: 10.1111/j.1365-2133.2008.08504.x

55. Bovenschen HJ, van Vlijmen-Willems IM, van de Kerkhof PC, van Erp PE. Identification of Lesional CD4+ CD25+ Foxp3+ Regulatory T Cells in Psoriasis. Dermatol (Basel Switzerland) (2006) 213(2):111-7. doi: 10.1159/ 000093849

56. Li B, Lei J, Yang L, Gao C, Dang E, Cao T, et al. Dysregulation of AktFOXO1 Pathway Leads to Dysfunction of Regulatory T Cells in Patients With Psoriasis. J Invest Dermatol (2019) 139(10):2098-107. doi: 10.1016/ j.jid.2018.12.035

57. Sugiyama H, Gyulai R, Toichi E, Garaczi E, Shimada S, Stevens SR, et al. Dysfunctional Blood and Target Tissue CD4+CD25high Regulatory T Cells in Psoriasis: Mechanism Underlying Unrestrained Pathogenic Effector T Cell Proliferation. J Immunol (Baltimore Md 1950) (2005) 174(1):164-73. doi: 10.4049/jimmunol.174.1.164

58. Zhang L, Li Y, Yang X, Wei J, Zhou S, Zhao Z, et al. Characterization of Th17 and FoxP3(+) Treg Cells in Paediatric Psoriasis Patients. Scand J Immunol (2016) 83(3):174-80. doi: 10.1111/sji.12404

59. Goodman WA, Levine AD, Massari JV, Sugiyama H, McCormick TS, Cooper KD. IL-6 Signaling in Psoriasis Prevents Immune Suppression by Regulatory T Cells. J Immunol (Baltimore Md 1950) (2009) 183(5):3170-6. doi: 10.4049/jimmunol.0803721
60. Goodman WA, Young AB, McCormick TS, Cooper KD, Levine AD. Stat3 Phosphorylation Mediates Resistance of Primary Human T Cells to Regulatory T Cell Suppression. J Immunol (Baltimore Md 1950) (2011) 186(6):3336-45. doi: 10.4049/jimmunol.1001455

61. Wang XY, Chen XY, Li J, Zhang HY, Liu J, Sun LD. MiR-200a Expression in CD4+ T Cells Correlates With the Expression of Th17/Treg Cells and Relevant Cytokines in Psoriasis Vulgaris: A Case Control Study. Biomed Pharmacother $=$ Biomed Pharmacother (2017) 93:1158-64. doi: 10.1016/ j.biopha.2017.06.055

62. Wang H, Peters T, Sindrilaru A, Kess D, Oreshkova T, Yu XZ, et al. TGFBeta-Dependent Suppressive Function of Tregs Requires Wild-Type Levels of CD18 in a Mouse Model of Psoriasis. J Clin Invest (2008) 118(7):2629-39. doi: $10.1172 /$ jci34916

63. Kimura A, Kishimoto T. IL-6: Regulator of Treg/Th17 Balance. Eur J Immunol (2010) 40(7):1830-5. doi: 10.1002/eji.201040391

64. Bovenschen HJ, van de Kerkhof PC, van Erp PE, Woestenenk R, Joosten I, Koenen HJ. Foxp3+ Regulatory T Cells of Psoriasis Patients Easily Differentiate Into IL-17A-Producing Cells and Are Found in Lesional Skin. J Invest Dermatol (2011) 131(9):1853-60. doi: 10.1038/jid.2011.139

65. Singh K, Gatzka M, Peters T, Borkner L, Hainzl A, Wang H, et al. Reduced CD18 Levels Drive Regulatory T Cell Conversion Into Th17 Cells in the CD18hypo Pl/J Mouse Model of Psoriasis. J Immunol (Baltimore Md 1950) (2013) 190(6):2544-53. doi: 10.4049/jimmunol.1202399

66. Ma L, Xue H, Gao T, Gao M, Zhang Y. Notch1 Signaling Regulates the Th17/ Treg Immune Imbalance in Patients With Psoriasis Vulgaris. Mediators Inflammation (2018) 2018:3069521. doi: 10.1155/2018/3069521

67. Long D, Chen Y, Wu H, Zhao M, Lu Q. Clinical Significance and Immunobiology of IL-21 in Autoimmunity. J Autoimmun (2019) 99:1-14. doi: 10.1016/j.jaut.2019.01.013

68. Niu J, Song Z, Yang X, Zhai Z, Zhong H, Hao F. Increased Circulating Follicular Helper T Cells and Activated B Cells Correlate With Disease Severity in Patients With Psoriasis. J Eur Acad Dermatol Venereol JEADV (2015) 29(9):1791-6. doi: 10.1111/jdv.13027

69. Wang Y, Wang L, Yang H, Yuan W, Ren J, Bai Y. Activated Circulating T Follicular Helper Cells Are Associated With Disease Severity in Patients With Psoriasis. J Immunol Res (2016) 2016:7346030. doi: 10.1155/2016/ 7346030

70. Caruso R, Botti E, Sarra M, Esposito M, Stolfi C, Diluvio L, et al. Involvement of Interleukin-21 in the Epidermal Hyperplasia of Psoriasis. Nat Med (2009) 15(9):1013-5. doi: 10.1038/nm.1995

71. Wang Y, Wang L, Shi Y, Wang F, Yang H, Han S, et al. Altered Circulating T Follicular Helper Cell Subsets in Patients With Psoriasis Vulgaris. Immunol Lett (2017) 181:101-8. doi: 10.1016/j.imlet.2016.09.008

72. Cai YH, Fleming C, Yan J. New Insights of T Cells in the Pathogenesis of Psoriasis. Cell Mol Immunol (2012) 9(4):302-9. doi: 10.1038/cmi.2012.15

73. Liu T, Li S, Ying S, Tang S, Ding Y, Li Y, et al. The IL-23/IL-17 Pathway in Inflammatory Skin Diseases: From Bench to Bedside. Front Immunol (2020) 11:594735. doi: 10.3389/fimmu.2020.594735

74. Papp KA, Tyring S, Lahfa M, Prinz J, Griffiths CE, Nakanishi AM, et al. A Global Phase III Randomized Controlled Trial of Etanercept in Psoriasis: Safety, Efficacy, and Effect of Dose Reduction. Br J Dermatol (2005) 152 (6):1304-12. doi: 10.1111/j.1365-2133.2005.06688.x

75. Reich K, Nestle FO, Papp K, Ortonne JP, Evans R, Guzzo C, et al. Infliximab Induction and Maintenance Therapy for Moderate-to-Severe Psoriasis: A Phase III, Multicentre, Double-Blind Trial. Lancet (London England) (2005) 366(9494):1367-74. doi: 10.1016/s0140-6736(05)67566-6

76. Barker J, Hoffmann M, Wozel G, Ortonne JP, Zheng H, van Hoogstraten H, et al. Efficacy and Safety of Infliximab vs. Methotrexate in Patients With Moderate-to-Severe Plaque Psoriasis: Results of an Open-Label, ActiveControlled, Randomized Trial (RESTORE1). Br J Dermatol (2011) 165 (5):1109-17. doi: 10.1111/j.1365-2133.2011.10615.x

77. Menter A, Tyring SK, Gordon K, Kimball AB, Leonardi CL, Langley RG, et al. Adalimumab Therapy for Moderate to Severe Psoriasis: A Randomized, Controlled Phase III Trial. J Am Acad Dermatol (2008) 58(1):106-15. doi: 10.1016/j.jaad.2007.09.010

78. Gottlieb AB, Blauvelt A, Thaçi D, Leonardi CL, Poulin Y, Drew J, et al. Certolizumab Pegol for the Treatment of Chronic Plaque Psoriasis: Results Through 48 Weeks From 2 Phase 3, Multicenter, Randomized, Double- 
Blinded, Placebo-Controlled Studies (CIMPASI-1 and CIMPASI-2). J Am Acad Dermatol (2018) 79(2):302-14.e6. doi: 10.1016/j.jaad.2018.04.012

79. Lebwohl M, Blauvelt A, Paul C, Sofen H, Węgłowska J, Piguet V, et al. Certolizumab Pegol for the Treatment of Chronic Plaque Psoriasis: Results Through 48 Weeks of a Phase 3, Multicenter, Randomized, Double-Blind, Etanercept- and Placebo-Controlled Study (CIMPACT). J Am Acad Dermatol (2018) 79(2):266-76.e5. doi: 10.1016/j.jaad.2018.04.013

80. Papp KA, Langley RG, Lebwohl M, Krueger GG, Szapary P, Yeilding N, et al. Efficacy and Safety of Ustekinumab, a Human Interleukin-12/23 Monoclonal Antibody, in Patients With Psoriasis: 52-Week Results From a Randomised, Double-Blind, Placebo-Controlled Trial (PHOENIX 2). Lancet (London England) (2008) 371(9625):1675-84. doi: 10.1016/S01406736(08)60726-6

81. Gottlieb AB, Leonardi C, Kerdel F, Mehlis S, Olds M, Williams DA. Efficacy and Safety of Briakinumab vs. Etanercept and Placebo in Patients With Moderate to Severe Chronic Plaque Psoriasis. Br J Dermatol (2011) 165 (3):652-60. doi: 10.1111/j.1365-2133.2011.10418.x

82. Blauvelt A, Papp KA, Griffiths CE, Randazzo B, Wasfi Y, Shen YK, et al. Efficacy and Safety of Guselkumab, an Anti-Interleukin-23 Monoclonal Antibody, Compared With Adalimumab for the Continuous Treatment of Patients With Moderate to Severe Psoriasis: Results From the Phase III, Double-Blinded, Placebo- and Active Comparator-Controlled VOYAGE 1 Trial. J Am Acad Dermatol (2017) 76(3):405-17. doi: 10.1016/ j.jaad.2016.11.041

83. Reich K, Armstrong AW, Langley RG, Flavin S, Randazzo B, Li S, et al. Guselkumab Versus Secukinumab for the Treatment of Moderate-to-Severe Psoriasis (ECLIPSE): Results From a Phase 3, Randomised Controlled Trial. Lancet (London England) (2019) 394(10201):831-9. doi: 10.1016/s01406736(19)31773-8

84. Thaçi D, Pinter A, Sebastian M, Termeer C, Sticherling M, Gerdes S, et al. Guselkumab Is Superior to Fumaric Acid Esters in Patients With Moderateto-Severe Plaque Psoriasis Who Are Naive to Systemic Treatment: Results From a Randomized, Active-Comparator-Controlled Phase IIIb Trial (POLARIS). Br J Dermatol (2020) 183(2):265-75. doi: 10.1111/bjd.18696

85. Reich K, Gooderham M, Thaçi D, Crowley JJ, Ryan C, Krueger JG, et al. Risankizumab Compared With Adalimumab in Patients With Moderate-toSevere Plaque Psoriasis (IMMvent): A Randomised, Double-Blind, ActiveComparator-Controlled Phase 3 Trial. Lancet (London England) (2019) 394 (10198):576-86. doi: 10.1016/s0140-6736(19)30952-3

86. Warren RB, Blauvelt A, Poulin Y, Beeck S, Kelly M, Wu T, et al. Efficacy and Safety of Risankizumab vs. Secukinumab in Patients With Moderate-toSevere Plaque Psoriasis (IMMerge): Results From a Phase III, Randomized, Open-Label, Efficacy-Assessor-Blinded Clinical Trial. Br J Dermatol (2021) 184(1):50-9. doi: 10.1111/bjd.19341

87. Thaçi D, Blauvelt A, Reich K, Tsai TF, Vanaclocha F, Kingo K, et al. Secukinumab is Superior to Ustekinumab in Clearing Skin of Subjects With Moderate to Severe Plaque Psoriasis: CLEAR, A Randomized Controlled Trial. J Am Acad Dermatol (2015) 73(3):400-9. doi: 10.1016/j.jaad.2015. 05.013

88. Blauvelt A, Reich K, Tsai TF, Tyring S, Vanaclocha F, Kingo K, et al. Secukinumab Is Superior to Ustekinumab in Clearing Skin of Subjects With Moderate-to-Severe Plaque Psoriasis Up to 1 Year: Results From the CLEAR Study. J Am Acad Dermatol (2017) 76(1):60-9.e9. doi: 10.1016/ j.jaad.2016.08.008

89. Bagel J, Blauvelt A, Nia J, Hashim P, Patekar M, de Vera A, et al. Secukinumab Maintains Superiority Over Ustekinumab in Clearing Skin and Improving Quality of Life in Patients With Moderate to Severe Plaque Psoriasis: 52-Week Results From a Double-Blind Phase 3b Trial (CLARITY). J Eur Acad Dermatol Venereol JEADV (2021) 35(1):135-42. doi: $10.1111 / j \mathrm{dv} .16558$

90. Griffiths CE, Reich K, Lebwohl M, van de Kerkhof P, Paul C, Menter A, et al. Comparison of Ixekizumab With Etanercept or Placebo in Moderate-toSevere Psoriasis (UNCOVER-2 and UNCOVER-3): Results From Two Phase 3 Randomised Trials. Lancet (London England) (2015) 386 (9993):541-51. doi: 10.1016/S0140-6736(15)60125-8

91. Gordon KB, Blauvelt A, Papp KA, Langley RG, Luger T, Ohtsuki M, et al. Phase 3 Trials of Ixekizumab in Moderate-To-Severe Plaque Psoriasis. New Engl J Med (2016) 375(4):345-56. doi: 10.1056/NEJMoa1512711
92. Blauvelt A, Gooderham M, Iversen L, Ball S, Zhang L, Agada NO, et al. Efficacy and Safety of Ixekizumab for the Treatment of Moderate-to-Severe Plaque Psoriasis: Results Through 108 Weeks of a Randomized, Controlled Phase 3 Clinical Trial (UNCOVER-3). J Am Acad Dermatol (2017) 77 (5):855-62. doi: 10.1016/j.jaad.2017.06.153

93. Lebwohl MG, Gordon KB, Gallo G, Zhang L, Paul C. Ixekizumab Sustains High Level of Efficacy and Favourable Safety Profile Over 4 Years in Patients With Moderate Psoriasis: Results From UNCOVER-3 Study. J Eur Acad Dermatol Venereol JEADV (2020) 34(2):301-9. doi: 10.1111/jdv.15921

94. Reich K, Augustin M, Thaçi D, Pinter A, Leutz A, Henneges C, et al. A 24Week Multicentre, Randomized, Open-Label, Parallel-Group Study Comparing the Efficacy and Safety of Ixekizumab vs. Fumaric Acid Esters and Methotrexate in Patients With Moderate-to-Severe Plaque Psoriasis Naive to Systemic Treatment. Br J Dermatol (2020) 182(4):869-79. doi: 10.1111/bjd.18384

95. Blauvelt A, Leonardi C, Elewski B, Crowley JJ, Guenther LC, Gooderham M, et al. A Head-to-Head Comparison of Ixekizumab vs. Guselkumab in Patients With Moderate-to-Severe Plaque Psoriasis: 24-Week Efficacy and Safety Results From a Randomized, Double-Blinded Trial. Br J Dermatol (2021) 184(6):1047-58. doi: 10.1111/bjd.19509

96. Lebwohl M, Strober B, Menter A, Gordon K, Weglowska J, Puig L, et al. Phase 3 Studies Comparing Brodalumab With Ustekinumab in Psoriasis. New Engl J Med (2015) 373(14):1318-28. doi: 10.1056/ NEJMoa1503824

97. Pinter A, Hoffmann M, Reich K, Augustin M, Kaplan K, Gudjónsdóttir SD, et al. A Phase 4, Randomized, Head-to-Head Trial Comparing the Efficacy of Subcutaneous Injections of Brodalumab to Oral Administrations of Fumaric Acid Esters in Adults With Moderate-to-Severe Plaque Psoriasis (CHANGE). J Eur Acad Dermatol Venereol JEADV (2021) 35(3):701-11. doi: $10.1111 /$ jdv.16932

98. Ghoreschi K, Balato A, Enerback C, Sabat R. Therapeutics Targeting the IL23 and IL-17 Pathway in Psoriasis. Lancet (London England) (2021) 397 (10275):754-66. doi: 10.1016/S0140-6736(21)00184-7

99. Nash P, Kirkham B, Okada M, Rahman P, Combe B, Burmester GR, et al. Ixekizumab for the Treatment of Patients With Active Psoriatic Arthritis and an Inadequate Response to Tumour Necrosis Factor Inhibitors: Results From the 24-Week Randomised, Double-Blind, Placebo-Controlled Period of the SPIRIT-P2 Phase 3 Trial. Lancet (London England) (2017) 389 (10086):2317-27. doi: 10.1016/S0140-6736(17)31429-0

100. Mease PJ, van der Heijde D, Ritchlin CT, Okada M, Cuchacovich RS, Shuler CL, et al. Ixekizumab, an Interleukin-17A Specific Monoclonal Antibody, for the Treatment of Biologic-Naive Patients With Active Psoriatic Arthritis: Results From the 24-Week Randomised, Double-Blind, Placebo-Controlled and Active (Adalimumab)-Controlled Period of the Phase III Trial SPIRIT-P1. Ann Rheum Dis (2017) 76(1):79-87. doi: 10.1136/annrheumdis-2016-209709

101. McInnes IB, Mease PJ, Kirkham B, Kavanaugh A, Ritchlin CT, Rahman P, et al. Secukinumab, a Human Anti-Interleukin-17A Monoclonal Antibody, in Patients With Psoriatic Arthritis (FUTURE 2): A Randomised, DoubleBlind, Placebo-Controlled, Phase 3 Trial. Lancet (London England) (2015) 386(9999):1137-46. doi: 10.1016/S0140-6736(15)61134-5

102. Ritchlin CT, Kavanaugh A, Merola JF, Schett G, Scher JU, Warren RB, et al. Bimekizumab in Patients With Active Psoriatic Arthritis: Results From a 48Week, Randomised, Double-Blind, Placebo-Controlled, Dose-Ranging Phase 2b Trial. Lancet (London England) (2020) 395(10222):427-40. doi: 10.1016/ S0140-6736(19)33161-7

103. Langley RG, Armstrong AW, Lebwohl MG, Blauvelt A, Hsu S, Tyring S, et al. Efficacy and Safety of Brodalumab in Patients With Psoriasis Who had Inadequate Responses to Ustekinumab: Subgroup Analysis of Two Randomized Phase III Trials. Br J Dermatol (2019) 180(2):306-14. doi: $10.1111 /$ bjd. 17318

104. Kimmel G, Chima M, Kim HJ, Bares J, Yao CJ, Singer G, et al. Brodalumab in the Treatment of Moderate to Severe Psoriasis in Patients When Previous Anti-Interleukin 17A Therapies Have Failed. J Am Acad Dermatol (2019) 81 (3):857-9. doi: 10.1016/j.jaad.2019.05.007

105. Antoniu SA. Discontinued Drugs 2011: Pulmonary, Allergy, Gastrointestinal and Arthritis. Expert Opin Invest Drugs (2012) 21(11):1607-18. doi: 10.1517/ 13543784.2012.712112

106. Raychaudhuri SK, Abria C, Raychaudhuri SP. Regulatory Role of the JAK STAT Kinase Signalling System on the IL-23/IL-17 Cytokine Axis in 
Psoriatic Arthritis. Ann Rheum Dis (2017) 76(10):e36. doi: 10.1136/ annrheumdis-2016-211046

107. Valenzuela F, Paul C, Mallbris L, Tan H, Papacharalambous J, Valdez H, et al. Tofacitinib Versus Etanercept or Placebo in Patients With Moderate to Severe Chronic Plaque Psoriasis: Patient-Reported Outcomes From a Phase 3 Study. J Eur Acad Dermatol Venereol JEADV (2016) 30(10):1753-9. doi: $10.1111 /$ jdv.13702

108. Clinical Trails. Available at: https://clinicaltrials.gov/ct2/show/ NCT01490632? cond=NCT01490632\&draw=2\&rank=1.

109. Clinical Trails. Available at: https://clinicaltrials.gov/ct2/show/ NCT01634087? cond=NCT01634087\&draw=1\&rank=1.

110. Clinical Trails. Available at: https://clinicaltrials.gov/ct2/show/ NCT02969018? cond=NCT02969018\&draw=2\&rank=1.

111. Forman SB, Pariser DM, Poulin Y, Vincent MS, Gilbert SA, Kieras EM, et al. TYK2/JAK1 Inhibitor PF-06700841 in Patients With Plaque Psoriasis: Phase IIa, Randomized, Double-Blind, Placebo-Controlled Trial. J Invest Dermatol (2020) 140(12):2359-70 e5. doi: 10.1016/j.jid.2020.03.962

112. Clinical Trails. Available at: https://clinicaltrials.gov/ct2/show/ NCT03895372? cond=NCT03895372\&draw=1\&rank=1.
113. Clinical Trails. Available at: https://clinicaltrials.gov/ct2/show/ NCT03924427? cond=NCT03924427\&draw=2\&rank=1.

Conflict of Interest: The authors declare that the research was conducted in the absence of any commercial or financial relationships that could be construed as a potential conflict of interest.

Publisher's Note: All claims expressed in this article are solely those of the authors and do not necessarily represent those of their affiliated organizations, or those of the publisher, the editors and the reviewers. Any product that may be evaluated in this article, or claim that may be made by its manufacturer, is not guaranteed or endorsed by the publisher.

Copyright (c) $2021 \mathrm{Hu}$, Wang, Gao, Zheng, Li, Mu and Tong. This is an open-access article distributed under the terms of the Creative Commons Attribution License (CC BY). The use, distribution or reproduction in other forums is permitted, provided the original author(s) and the copyright owner(s) are credited and that the original publication in this journal is cited, in accordance with accepted academic practice. No use, distribution or reproduction is permitted which does not comply with these terms. 